\title{
Evaluación de la durabilidad de bloques de tierra-cemento-sisal armado, al someterlos a la acción de iones cloruros
}

\section{Durability of reinforced adobe exposed to chloride ions}

\author{
R. E. Malavé(*), M. Gómez(*), G. Sosa(*), E. Anzola(*) y A. Giménez(*)
}

Recepción/Received: 11-XI-05

Aceptación/Accepted: 25-III-06

\section{RESUMEN}

La tierra-cemento-sisal es un material cuyo uso se encuentra muy difundido en toda Latinoamérica, entre sus principales limitaciones está la inestabilidad volumétrica ante el agua y ambientes agresivos. Por tal motivo, en este trabajo se evaluó el comportamiento electroquímico de bloques de tierra-cemento-sisal armado expuestos durante 1.000 días a un ambiente marino simulado. Las probetas utilizadas fueron bloques de tierra-cemento-sisal incorporándole internamente barras de acero de $3 / 8$ de pulg. Las probetas se sometieron a un rociado quincenal: las de ambiente natural urbano con agua potable y las de ambiente marino simulado con una solución al 3\% de cloruro de sodio. La penetración de cloruros se determinó extrayendo polvillo y siguiendo el método de Mohr. Para los ensayos electroquímicos se usó el corrosímetro Gecor 6, midiendo el potencial eléctrico $\left(E^{\circ}\right)$ y la intensidad de corrosión (icorr). Finalmente, se procedió al análisis y evaluación de los resultados, concluyendo que en todos los casos la cantidad de cloruros libres presentes es suficiente para despasivar el acero de refuerzo, verificando que en el sistema el elemento que más protege es el mortero de enfoscado, por lo tanto, construcciones con este tipo de mezclas de tierra-cemento-sisal no son recomendables en zonas marinas o industriales.

Palabras clave: adobe, cloruros, refuerzo metálico, durabilidad, corrosión.

\section{SUMMARY}

One of the primary shortcomings of adobe, a dried mud block stabilized with sisal hemp and cement widely used across all of Latin America, is its dimensional instability when exposed to water or aggressive environments. The present paper evaluates the electrochemical performance of reinforced adobe block after 1,000 days of exposure to a simulated marine environment. The specimens used were adobe blocks internally reinforced with 3/8inch steel bars. The specimens were watered every two weeks: one group with potable water to simulate a natural urban environment and the other with a 3\% sodium chloride solution to simulate a marine environment. Chloride penetration in powder extracted from the specimens was determined using the Mohr method. Electrochemical measurements included Gecor 6 electric potential $\left(E^{\circ}\right)$ and corrosion intensity (icorr) readings. The final conclusion drawn from an analysis of the results was that in all cases the amount of free chlorides present sufficed to depassivate reinforcing steel and that the system component providing the most effective protection was the rough casting mortar. Consequently, this type of adobe mixes is not recommended for use in marine or industrial environments.

Keywords: adobe, chlorides, metallic reinforcement, durability, corrosion.

(*) Departamento de Ingeniería de Construcción. Decanato de Ingeniería Civil. Universidad Centroccidental Lisandro Alvarado, Barquisimeto (Venezuela). 


\section{INTRODUCCIÓN}

En Latinoamérica y especialmente en Venezuela, la crisis de vivienda y el aumento desmesurado del costo de las mismas ha propiciado el uso de bloques de tierra-cemento-sisal en muros portantes armados justificado por su facilidad de fabricación, abundancia de materiales y bajo costo. En tal sentido resulta imperante determinar la vulnerabilidad de estas construcciones y, en especial, estudiar su durabilidad.

En ese contexto se puede establecer que uno de los fenómenos de mayor incidencia sobre la durabilidad de las construcciones armadas es la corrosión, por constituir una de las formas más común de agresión del medio en las estructuras de acero. Este problema puede hacerse más agudo en las construcciones de tierra objeto de este estudio, ya que los bloques de tierra-cemento-sisal armado están constituidos por materiales de tierra sin ningún proceso de cocción, cuyo contenido de cemento como aglomerante es bajo, alrededor de un $5 \%$ en el bloque de tierra-cemento-sisal propiamente dicho, hasta un $20 \%$ en el mortero de enfoscado y hasta un $28 \%$ en el mortero de refuerzo (1).

El fenómeno de corrosión es especialmente importante en ambientes marinos, en donde la presencia de los iones cloruros tiene la propiedad de destruir en forma puntual la capa pasiva que se forma habitualmente en el acero, provocando una corrosión por picadura. Los cloruros pueden estar en el material, ya sea incluido en sus componentes o penetrando desde el medio exterior a través de la red de poros. Si se toma como referencia al hormigón, tres aspectos se han mencionado como importantes para el caso de los cloruros que penetran desde el exterior, éstos son: el tiempo que tardan en llegar a la armadura, la proporción que induce la despasivación y la velocidad de corrosión que provocan al desencadenar el proceso. La velocidad de avance se ha establecido que responde al comportamiento matemático de una raíz cuadrada del tiempo de exposición, pero el cálculo del avance $X_{C l}$ es complejo, debido a la multiplicidad de variables que lo afectan entre ellos la composición del material (2).

$$
X_{c l}=K_{c l} \times \sqrt{t}
$$

Por otro lado, una vez dentro los cloruros pueden estar en dos formas: como cloruros "libres", es decir, en forma de iones en el agua contenida en los poros, los cuales pueden actuar agresivamente sobre las armaduras y como cloruros "combinados", quienes forman parte de las fases hidratadas del cemento, fundamentalmente como cloroaluminatos. La suma de libres y combinados se suele llamar cloruros "totales". Aunque son los libres

\section{INTRODUCTION}

In Latin America and particularly in Venezuela, the housing crisis and the steep rise in construction costs have fostered the building of reinforced bearing walls with adobe, a low cost, readily manufactured product for which there is an abundant supply of raw materials (dried mud, sisal hemp and cement). Determining the vulnerability and durability of such buildings is therefore imperative.

One of the contingencies limiting durability in reinforced construction is corrosion, certainly among the most common effects of environmental action on steel structures. This problem may be intensified in the soil-based structures studied here, inasmuch as the earthen components of reinforced adobe block are not fired or baked and the cement binder content is low, at around 5\% of the block per se, up to $20 \%$ of the rough casting and $28 \%$ of the reinforcement mortar (1).

Corrosion is an especially relevant issue in marine environments where chloride ions can destroy localized areas of the passive layer that generally covers the steel, puncturing the rebar. The chlorides in question may exist in the components or penetrate the material from an external source through the pore network. In concrete, the three key aspects considered in connection with chloride penetration from external sources are: the time it takes the ions to reach the reinforcement, the proportion that induces depassivation and the corrosion rate once the process is underway. While the rate of corrosion spread is a factor of the square root of exposure time, calculating the rate for $X_{C l}$ is complex due to the many variables involved, material composition among them (2).

Moreover, once inside a structure, chlorides may adopt two forms: "free" chlorides, or ions in the water trapped in the pores in the mortar that may attack reinforcing bars, or "combined" chlorides that form a part of hydrated cement phases, primarily as chloroaluminates. The sum of free and combined ions gives the "total" chloride content. Although free or water-soluble ions are the ones that actually cause corrosion, the total chloride count is 
o solubles en agua los que en realidad pueden provocar la corrosión, es conveniente determinar también el contenido de cloruros totales, ya que los cloruros combinados pueden volver a la disolución y tornarse agresivos (3).

De acuerdo a esas premisas, los autores en trabajos previos $(1,4)$ evaluaron las propiedades de porosidad, absorción capilar y permeabilidad al agua en bloques de tierra-cemento-sisal, encontrando valores muy por debajo a los recomendados para el hormigón. En consecuencia, consideraron oportuno estudiar el comportamiento electroquímico, el ingreso de los cloruros y la apariencia de las barras de acero de ese material al tener un tiempo de exposición de 1.000 días.

\section{PARTE EXPERIMENTAL}

\subsection{Materiales y métodos}

Los muros portantes de tierra-cemento-sisal armado están constituidos por bloques de suelo-cemento-sisal denominados adobes, cuyas dimensiones son $10 \mathrm{~cm}$ de alto, $20 \mathrm{~cm}$ de ancho y $40 \mathrm{~cm}$ de longitud. Para el armado horizontal de esos muros se usan bloques que tienen surcos de $5 \mathrm{~cm}$ de diámetro en donde se incorpora la barra de acero de diámetro 3/8 de pulg., alrededor de esta barra se adiciona un mortero líquido, denominado mortero del refuerzo, que debe garantizar la adecuada y necesaria pasivación del acero. En este trabajo se usaron dos tipos de mortero de refuerzo, $\operatorname{MRD}(\mathrm{a} / \mathrm{c}=0,5)$ y uno con menor relación agua cemento $\operatorname{MRE}(\mathrm{a} / \mathrm{c}=0,4)$. Finalmente, y como acabado, el muro es revestido con un mortero de arena amarilla, denominado mortero de enfoscado, cuyo espesor oscila entre $1,0 \mathrm{~cm}$ y $1,5 \mathrm{~cm}$. En este caso se utilizaron también dos morteros de enfoscado, el MFA, con $12 \%$ de cemento, y MFB, con menor contenido de cemento, $9 \%$, revestido con una película de material impermeabilizante comercial a base de cemento. Los morteros MFA y MRD fueron caracterizados por los autores en trabajo previo (1).

Para este estudio se diseñaron cuatro tipos de probetas, conformadas por los bloques de armado horizontal con los surcos y las barras mencionadas. La probeta se observa en la Figura 1 y para su elaboración se siguió el método de Pérez G. y colaboradores (1). De acuerdo con el tipo de material usado las probetas se identificaron como: MFA (12\%) Adobe-MRD (a/c=0,5), MFA (12\%), Adobe-MRE $(\mathrm{a} / \mathrm{c}=0,4), \operatorname{MFB}(9 \%)$, Adobe-MRD $(\mathrm{a} / \mathrm{c}=0,5)$ y $\operatorname{MFB}(9 \%)$ Adobe-MRE $(\mathrm{a} / \mathrm{c}=0,4)$. Transcurrido el periodo de curado de 28 días al aire, las probetas se expusieron durante 1.000 días, en dos grupos por duplicado, uno al ambiente natural urbano, rociando quincenalmente con agua potable, previa a las mediciones y el likewise important, for if combined chlorides dissolve they can also be damaging (3).

In this same vein, the authors evaluated porosity, capillary absorption and water permeability of adobe block in previous studies $(1,4)$, finding the values to be much lower than recommended for concrete. It was therefore felt that such findings should be completed with a study of electrochemical performance, chloride intake and the physical appearance of steel bars in this material after exposure to simulated environments for 1,000 days.

\section{EXPERIMENTAL}

\subsection{Materials and methods}

Adobe bearing walls are made of $10 \mathrm{~cm}$ high, $20 \mathrm{~cm}$ wide and $40 \mathrm{~cm}$ long dried mud bricks containing sisal hemp and cement known as adobe. These walls are horizontally reinforced with 3/8-inch diameter steel bars. Housed in 5-cm diameter holes running through some of the blocks, these bars are covered with a liquid mortar called reinforcement mortar that prompts steel passivation. Two types of reinforcement mortar were used in this survey, one with a higher $(M R D: w / c=0.5)$ and the other with a lower $(M R E: W / c=0.4)$ water-cement ratio. Finally, the walls are faced with a 1.0- to 1.5-cm layer of yellow sand mortar called rough casting mortar or stucco. The two types of rough casting used in this study were MFA, with $12 \%$ cement, and MFB, with a lower cement content (9\%) but protected with commercial cement-base weatherproof film. Mortars MFA and MRD were characterized by the authors in a previous paper (1).

Four types of specimens were designed for this survey, consisting in horizontal reinforcing block with the aforementioned pierce holes and bars. A sketch of the specimen, manufactured with the Pérez $G$. et al. (1) method, is given in Figure 1. Depending on the type of material used the specimens were identified as follows: MFA (12\%), Adobe-MRD (w/c=0.5), MFA (12\%), Adobe-MRE $(w / c=0.4), \operatorname{MFB}(9 \%)$, Adobe-MRD $(w / c=0.5)$ and $M F B$ (9\%), Adobe-MRE (w/c=0.4). After the initial 28-day air curing period, the specimens were divided into two groups containing two replicates each. Both were exposed for 1,000 days: one to a natural urban environment that involved sponging with potable water every two 
otro grupo a un ambiente marino simulado con el rociado de una solución al 3\% de cloruro de sodio. Esto se hacía para simular en el primer caso humedecimiento normal por efecto de lluvia y en el segundo la acción de la niebla salina.

\subsection{Ensayos}

a) Potencial y velocidad de corrosión

Para realizar las mediciones y garantizar la uniformidad en las condiciones de humedad, las probetas se mojaban con una esponja de manera homogénea, sin lavar la superficie, durante un día previo a la medida del potencial y durante dos horas antes de la medición. Las medidas, tanto de potencial como de velocidad de corrosión, fueron efectuadas con el corrosímetro Gecor 6, equipo que aplica a la armadura una señal eléctrica de pequeña amplitud obteniendo la resistencia a la polarización mediante el cociente entre la variación del potencial y la intensidad, confinando el área de acero de la probeta en una longitud de $10 \mathrm{~cm}$. Este equipo utiliza un electrodo de cobre/sulfato de cobre de referencia.

b) Penetración de cloruros e inspección visual

A los 200 días y a los 1.000 días de exposición se tomaron en las probetas muestras del mortero de enfoscado, del bloque propiamente y del mortero de refuerzo, tanto por encima como por debajo de la barra de acero, extrayendo el polvo seco y tomando precauciones para no contaminar la muestra de un mortero con la del bloque o con la del otro mortero, y tanto para las probetas expuestas al ambiente natural como para las del ambiente marino simulado. Para determinar cuantitativamente la cantidad de cloruros libres que penetraron a través de los morteros de enfoscado, adobe y mortero de refuerzo, se utilizó el método de Mohr. La preparación se hizo weeks prior to measuring, and the other to a marine environment, simulated by bi-weekly sponging with a $3 \%$ sodium chloride solution. This was done to simulate normal moistening due to rainfall in the former and saline fog in the latter.

\subsection{Assays}

a) Electric potential and corrosion rate

The specimens were uniformly sponged, without washing the surface, the day before potential was measured and for two hours prior to measurement to ensure uniform moisture. Both the electric potential and corrosion rate measurements were taken with a GeCor 6, a device that applies a small electrical signal to the reinforcing steel. The polarization resistance is then determined by computing the variation in potential divided by the current over a 10-cm length of bar. This instrument uses a copper/copper sulphate reference electrode.

\section{b) Chloride penetration and visual inspection}

After 200 and 1,000 days of exposure, the adobe as well as the rough casting and reinforcement mortar in both natural and marine assay specimens were sampled above and below the rebar, extracting the dry powder with care to ensure sample purity (i.e., preventing contamination of adobe by mortar powder and vice-versa). The free chlorides penetrating the rough casting mortar, adobe and reinforcement mortar were quantified with the Mohr method. Samples were prepared as described in the DURAR-CYTED Manual (2) and three readings were taken for each. At the end of the exposure time the block was visually inspected and the bars were removed to

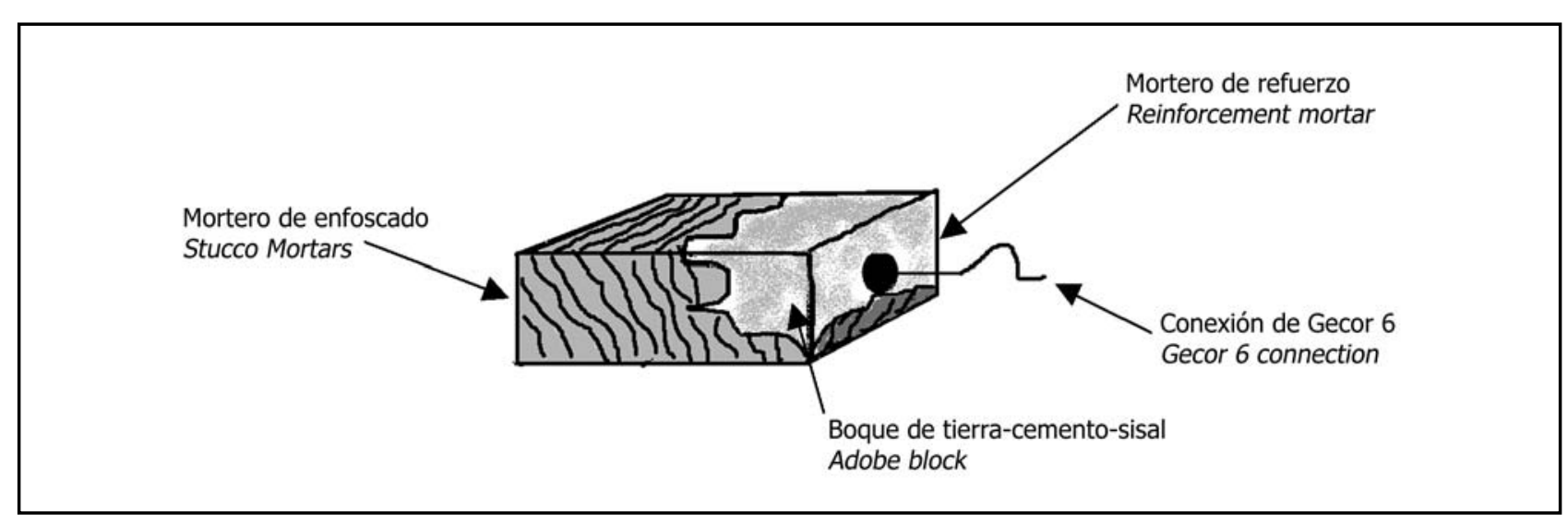

Figura 1. Probeta para ensayos electroquímicos.

Figure 1. Specimen for electrochemical testing. 
siguiendo el método establecido en el manual DURARCYTED (2), cada muestra se verificó por triplicado. Al finalizar el tiempo de exposición se realizó también una inspección visual de los bloques y se extrajeron las barras para cuantificar los daños de pérdida de espesor en forma porcentual.

\section{RESULTADOS Y DISCUSIÓN}

\subsection{Potencial de corrosión}

Los valores de potencial eléctrico medidos en los cuatro tipos de probetas se representan en las gráficas de la Figura 2 ( $a, b, c, d)$. Los criterios de evaluación usados fueron los del Manual DURAR-CYTED (2), que expresan un estado de pasividad en la barra de acero para valores mayores a -200 de $\mathrm{mV}$ y un nivel de daño despreciable. Valores entre $-200 \mathrm{mV}$ y $-350 \mathrm{mV}$, indican un estado de incertidumbre en la corrosión del acero y valores menores a -350 mV indican una alta actividad de corrosión en la barra de acero.

Según lo reflejado en la gráfica a) de la Figura 2, los valores de potencial de corrosión para las probetas de tierra-cemento-sisal tipo $\operatorname{MFB}(9 \%)-\operatorname{MRE}(a / c=0,4)$ expuestas en ambiente salino se mantuvieron en el rango desde $-600 \mathrm{mV}$ hasta $0 \mathrm{mV}$, observándose hasta los 200 días de exposición valores activos $\leq-350 \mathrm{mV}$, sin embargo después de los 800 días de exposición se observan valores de mayor actividad alrededor de -350 $\mathrm{mV}$ o más negativos, lo que indica una variación entre el estado pasivo y una actividad alta de corrosión en el acero de refuerzo. Por otra parte, los valores de potencial de corrosión para las probetas de este mismo tipo expuestas a ambiente natural se mantuvieron en el rango de incertidumbre o de pasividad, por encima de la línea límite de $-350 \mathrm{mV}$.

Los valores de potencial de corrosión correspondientes a las probetas de tierra-cemento-sisal tipo MFB (9\%) - $\operatorname{MRD}(a / c=0,5)$ expuestas en ambiente marino simulado, mostradas en la grafica b) de la Figura 2, oscilaron en el rango desde $-1.100 \mathrm{mV}$ hasta $-100 \mathrm{mV}$, observándose desde los 200 días un acercamiento a valores activos de potencial con mayor tendencia hacia la zona activa de corrosión en el acero de refuerzo. Para las probetas de este mismo tipo expuestas en ambiente natural, estos valores fluctuaron entre $-700 \mathrm{mV}$ y $-100 \mathrm{mV}$, lo que revela una actividad de corrosión moderada, con posibles daños por corrosión localizada y una tendencia a la estabilización hacia los días finales de exposición.

Para las probetas de tierra-cemento-sisal tipo MFA $(12 \%)$ - MRE $(a / c=0,4)$ expuestas en ambiente salino los valores de potencial de corrosión representados en la determine the damage in terms of percentage reduction in diameter.

\section{RESULTS AND DISCUSSION}

\subsection{Corrosion potential}

The electric potential values measured in the four types of specimens are shown in the graphs in Figure 2 ( $a, b$, $c, d)$. The evaluation criteria used were as set out in the DURAR-CYTED Manual (2), according to which steel bar passivity values higher than $-200 \mathrm{mV}$ signify negligible damage. Values from $-200 \mathrm{mV}$ to $-350 \mathrm{mV}$ signify uncertainty about steel corrosion and values of under $-350 \mathrm{mV}$ are indicative of high corrosion activity in the steel.

According to graph a) in Figure 2, the corrosion potential values for MFB (9\%) - MRE ( $/ \mathrm{c}=0.4)$ type adobe specimens exposed to a saline environment ranged from -600 to $0 \mathrm{mV}$, with values of $\leq-350 \mathrm{mV}$ after 200 days; after 800 days, in turn, values of around $-350 \mathrm{mV}$ or lower were observed, indicating steadily declining passivity and a high degree of corrosion in the reinforcing steel. The corrosion potential values for this same type of specimens exposed to a natural environment remained in the uncertain or passivity zones, above the $-350-\mathrm{mV}$ threshold.

The corrosion potential values for the MFB (9\%) - MRD $(w / c=0.5)$ adobe specimens exposed to a simulated marine environment, shown in graph b) in Figure 2, fluctuated from $-1100 \mathrm{mV}$ to $-100 \mathrm{mV}$, with active potential values observed in the reinforcing steel after 200 days, when a tendency toward active corrosion was observed. This same type of specimens exposed to a natural environment exhibited values ranging from $-700 \mathrm{mV}$ to $-100 \mathrm{mV}$, indicative of moderate corrosion with possible localized corrosion damage and a tendency toward stabilization in the latter days of the assay period.

The corrosion potential values plotted in Figure 2, graph c) for MFA (12\%) - MRE (w/c=0.4) type adobe specimens exposed to a saline environment ranged from -600 
grafica c) de la Figura 2 oscilaron dentro del rango de -600 $\mathrm{mV}$ hasta $-250 \mathrm{mV}$, con una tendencia a acercarse hacia el valor límite -350 mV después de los 200 días de exposición, lo que demuestra una actividad alta de corrosión en las barras de acero de refuerzo y alto riesgo de daño por corrosión en la armadura por ataque de cloruros.

Los valores de potencial de corrosión para las probetas de este mismo tipo expuestas a ambiente natural oscilaron en valores menos negativos a $-250 \mathrm{mV}$, relacionados a una condición pasiva en el acero de refuerzo y un riesgo de daño despreciable.
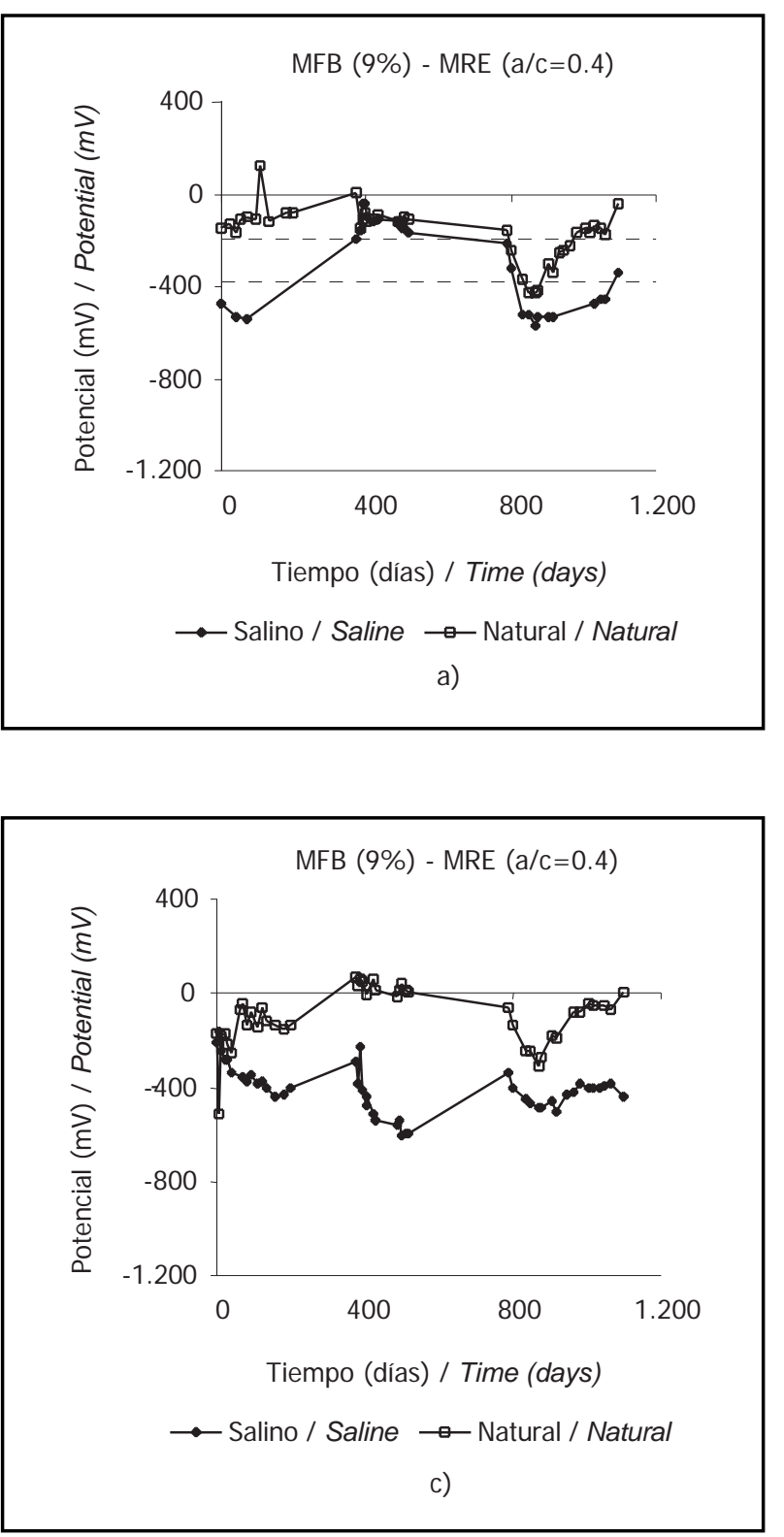

Figura 2. Potencial de corrosión de probetas de tierra-cemento-sisal. Figure 2. Corrosion potential in adobe specimens. to $-250 \mathrm{mV}$, with a tendency to converge on the $-350-\mathrm{mV}$ threshold value after 200 days of exposure, indicating the presence of corrosion in the reinforcing steel bars and a high risk of corrosion damage due to chloride attack.

The corrosion potential for this same type of specimens exposed to a natural environment hovered around values less negative than $-250 \mathrm{mV}$, associated with reinforcement steel passivity and a negligible risk of damage.
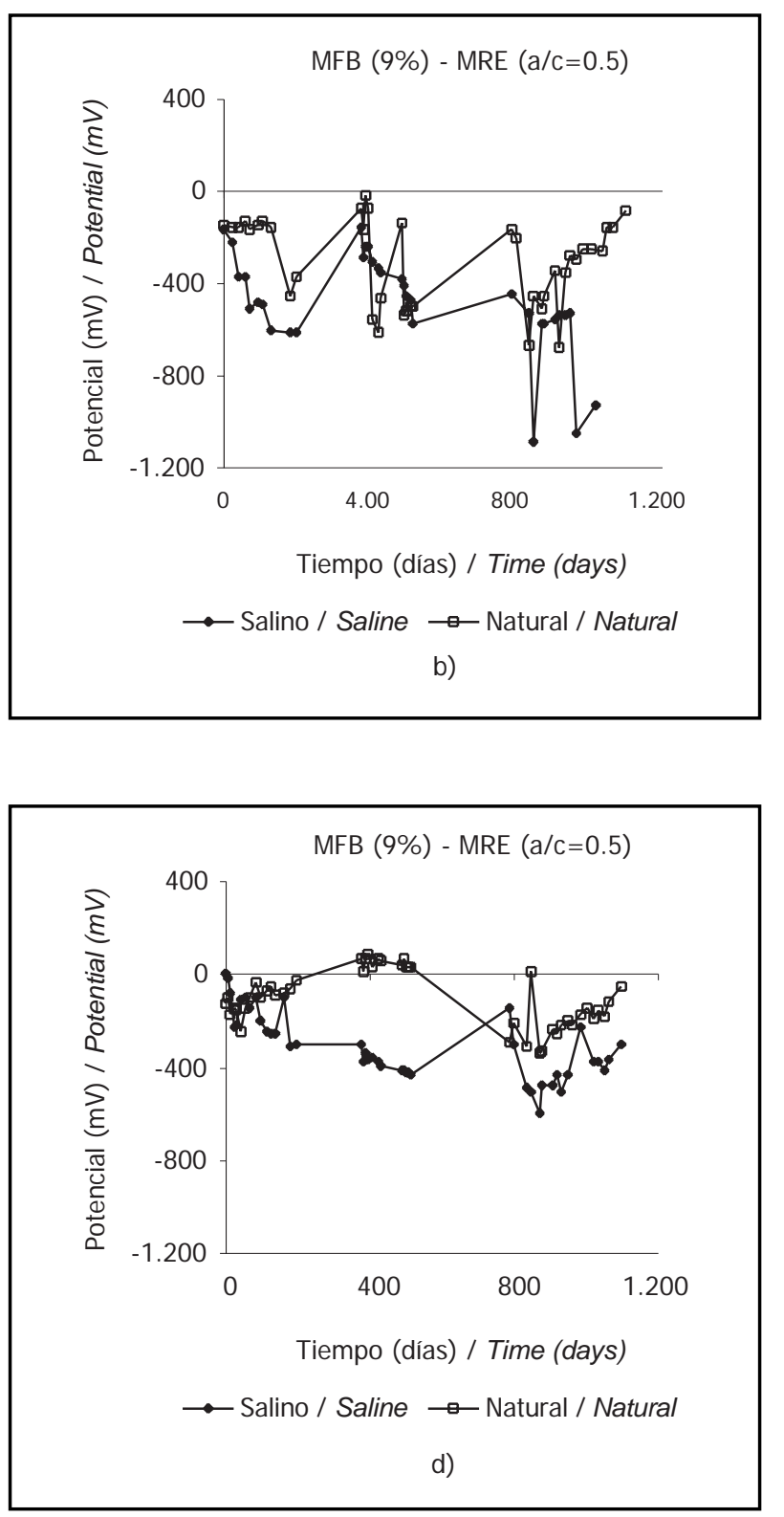

d) 
Para las probetas de tierra-cemento-sisal tipo MFA ( $12 \%$ ) - $\operatorname{MRD}(a / c=0,5)$ expuestas en ambiente marino simulado los valores de potencial de corrosión representados en la gráfica d) de la Figura 2 se mantuvieron en el rango desde $-600 \mathrm{mV}$ hasta $-150 \mathrm{mV}$, con una tendencia al valor límite -350 mV luego de los 200 días de exposición, lo que demuestra una actividad alta de corrosión en las barras de acero y alto riesgo de daño por corrosión en la armadura por ataque de cloruros. Los valores de potencial de corrosión para las probetas de este mismo tipo expuestas a ambiente natural se mantuvieron por encima de $-350 \mathrm{mV}$, valores relacionados a una condición pasiva en el acero y un riesgo de daño despreciable.

\subsection{Velocidad de corrosión}

Se consideraron los criterios de evaluación del Manual DURAR-CYTED (2), que expresan que para valores de icorr menores de $0,1 \mu \mathrm{A} / \mathrm{cm}^{2}$ el nivel de corrosión es despreciable, entre $0,1-0,5 \mu \mathrm{A} / \mathrm{cm}^{2}$ es moderado, entre $0,5-1 \mu \mathrm{A} / \mathrm{cm}^{2}$ es elevado y para valores mayores de $1 \mu \mathrm{A} / \mathrm{cm}^{2}$ el nivel de corrosión es muy elevado. Estos valores consideran la presencia de corrosión generalizada.

Al evaluar los resultados de velocidad de corrosión para los tipos de probetas de tierra-cemento-sisal en estudio MFB $(9 \%)-\operatorname{MRE}(a / c=0,4), \operatorname{MFB}(9 \%)-\operatorname{MRD}(a / c=0,5), \operatorname{MFA}$ $(12 \%)-\operatorname{MRE}(a / c=0,4)$ y MFA $(12 \%)-\operatorname{MRD}(a / c=0,5)$, se observó que al llegar a los 800 días de exposición las barras se encuentran en el rango moderado, entre $0,1-0,5 \mu \mathrm{A} / \mathrm{cm}^{2}$, destacando los mayores valores en las probetas expuestas al medio salino, con excepción de la probeta MFB $(9 \%)$ - MRD $(a / c=0,5)$, en ambiente natural que arrojó valores sostenidos superiores a $1 \mu \mathrm{A} / \mathrm{cm}^{2}$.

\subsection{Penetración de cloruros}

El criterio de valoración empleado para evaluar los valores de porcentaje de cloruros de las probetas ensayadas ha sido el propuesto por el manual de inspección de obras dañadas por corrosión, que establece qué porcentajes de cloruros entre $0,05 \%$ a $0,1 \%$ en relación al peso de hormigón o muestra, son suficientes para despasivar el acero de refuerzo.

Para las probetas expuestas en ambiente natural se observó un incremento de los cloruros, durante el tiempo de exposición, por lo cual se infiere que los cloruros provenientes del agua potable se fueron acumulando en las probetas.

Las muestras de polvillo extraídas de los morteros de refuerzo en las probetas a los 200 días de exposición reportaron en ambiente natural valores por debajo del nivel de activación, esto es, en las probetas MFB (9\%) - $\operatorname{MRE}(a / c=0,5)$ se encontró un valor promedió de
The corrosion potential values plotted in Figure 2, graph d) for MFA (12\%) - MRD $(w / c=0.5)$ type adobe specimens exposed to a saline environment ranged from -600 to $150 \mathrm{mV}$, with a tendency to converge on the $-350-\mathrm{mV}$ threshold value after 200 days of exposure, indicating the presence of corrosion in the reinforcing steel bars and a high risk of corrosion damage due to chloride attack. The corrosion potential for this same type of specimens exposed to a natural environment was consistently higher than -350 $\mathrm{mV}$ and therefore associated with reinforcing steel passivity and a negligible risk of damage.

\subsection{Corrosion rate}

The DURAR-CYTED (2) evaluation criteria used specify that for icorr values of less than $0.1 \mu \mathrm{A} / \mathrm{cm}^{2}$, corrosion is negligible; for values between 0.1 and $0.5 \mu \mathrm{A} / \mathrm{cm}^{2}$, moderate; for values ranging from 0.5 to $1 \mu A / \mathrm{cm}^{2}$, severe; and for values of over $1 \mu \mathrm{A} / \mathrm{cm}^{2}$, very severe. The above criteria refer to the presence of widespread corrosion.

According to the corrosion rates found for adobe specimens MFB (9\%) - MRE (w/c=0.4), MFB (9\%) - MRD $(w / c=0.5), M F A(12 \%)-M R E(w / c=0.4)$ and MFA (12\%) - $M R D(w / c=0.5)$, after 800 days of exposure the bars were moderately corroded, with values ranging from 0.1 to $0.5 \mu \mathrm{A} / \mathrm{cm}^{2}$. The saline environment rates were higher with one exception, namely the MFB (9\%) $\operatorname{MRD}(a / c=0.5)$ specimen exposed to a natural environment, which exhibited figures consistently higher than $1 \mu \mathrm{A} / \mathrm{cm}^{2}$.

\subsection{Chloride penetration}

The criterion used to evaluate the chloride percentages found in the test specimens was as proposed in the inspection manual on works damaged by corrosion, which provides that chloride percentages of from $0.05 \%$ to $0.1 \%$ by concrete or sample weight are sufficient to depassivate the reinforcing steel.

As chloride content was observed to rise in the specimens exposed to a natural environment during the assay period, it was deduced that the chlorides in the potable water gradually accumulated in the specimens.

The 200-day powdery samples taken from the reinforcement mortar in specimens exposed to natural environmental conditions showed values below the activation threshold, i.e., the mean value found for specimens MFB (9\%) - MRE ( $w / c=0.5)$ was $0.0394 \%$; for specimens 
$0,0394 \%$, en las probetas MFB $(9 \%)-\operatorname{MRD}(a / c=0,4)$ el valor fue de $0,0184 \%$, las probetas MFA (12\%) - MRE $(a / c=0,4)$ arrojaron $0,016 \%$ y finalmente las probetas MFA $(12 \%)$ - MRD $(a / c=0,5)$ reportaron $0,0158 \%$. Sin embargo, en ambiente marino simulado el porcentaje de cloruros de los morteros de refuerzo logró superar el límite establecido, reportando en las probetas MFB (9\%) - MRE $(a / c=0,5)$ un valor de $0,1365 \%$, en las probetas MFB $(9 \%)$ - MRD $(a / c=0,4)$ el valor fue de $0,1339 \%$, las probetas MFA $(12 \%)$ - MRE $(a / c=0,4)$ arrojaron un valor atípico de $0,1549 \%$ y finalmente en las probetas MFA (12\%) - MRD $(a / c=0,5)$ la presencia de cloruros fue de $0,0814 \%$.

Las muestras del polvillo extraídas de los morteros de refuerzo de las probetas a los 1.000 días de exposición, tanto en ambiente natural como en ambiente marino, reportaron porcentajes de cloruros libres superiores al requerido para la despasivación del acero, sólo las probetas MFA ( $12 \%$ ) en ambiente natural arrojaron un valor levemente inferior, esto es de $0,0435 \%$ para MFA (12\%) - MRD $(a / c=0,5)$ y $0,0420 \%$ para MFA $(12 \%)$ - MRD $(a / c=0,4)$. En las gráficas a y b de la Figura 3 se presentan los porcentajes de cloruros en función de la profundidad, observándose en la gráfica a) que en todos los casos los cloruros están por encima de 0,2\%. Para el caso del ambiente natural, en la gráfica b), los valores que están por encima del rango de pasivación $(0,05 \%$ $0,1 \%)$ corresponden al mortero de refuerzo $(5 \mathrm{~cm}$ de profundidad), indicando que los cloruros lograron penetrar y acumularse alrededor de la barra.
MFB (9\%) - MRE $(w / c=0.5)$ it was $0.0184 \%$; for MFA $(12 \%)-\operatorname{MRE}(w / c=0.4), 0.016 \%$; and for specimens MFA (12\%) - MRD (w/c=0.5), $0.0158 \%$. In the simulated marine environment, however, the percentage of chlorides in the reinforcement mortar exceeded the established limit, with specimens MFB (9\%) - MRE $(w / c=0.5)$ exhibiting a value of $0.1365 \%$; specimens MFB (9\%) - MRD $(w / c=0.4), 0.1339 \%$; specimens MFA (12\%) $\operatorname{MRE}(w / c=0.4)$ an atypical $0.1549 \%$; and finally specimens MFA (12\%) - MRD (w/c=0.5), 0.0814\%.

The 1,000-day powdery samples taken from the reinforcement mortar in specimens exposed to both natural and marine environmental conditions showed free chloride values above the threshold required to depassivate steel. The sole exceptions were the MFA (12\%) natural environment specimens, which had slightly lower values, i.e., $0.0435 \%$ for MFA (12\%) -MRD (w/c=0.5) and $0.0420 \%$ for MFA (12\%) - MRD $(w / c=0.4)$. Chloride percentage is plotted versus depth in Figure 3, graphs a and $b$. Note that in graph a) chloride content exceeds $0.2 \%$ in all cases. Under natural environmental conditions, graph b), the values falling outside the passivation range $(0.05 \%$ to $0.1 \%)$ correspond to the reinforcement mortar $(5 \mathrm{~cm}$ deep), indicating that the chloride ions were able to penetrate and accumulate around the rebar.

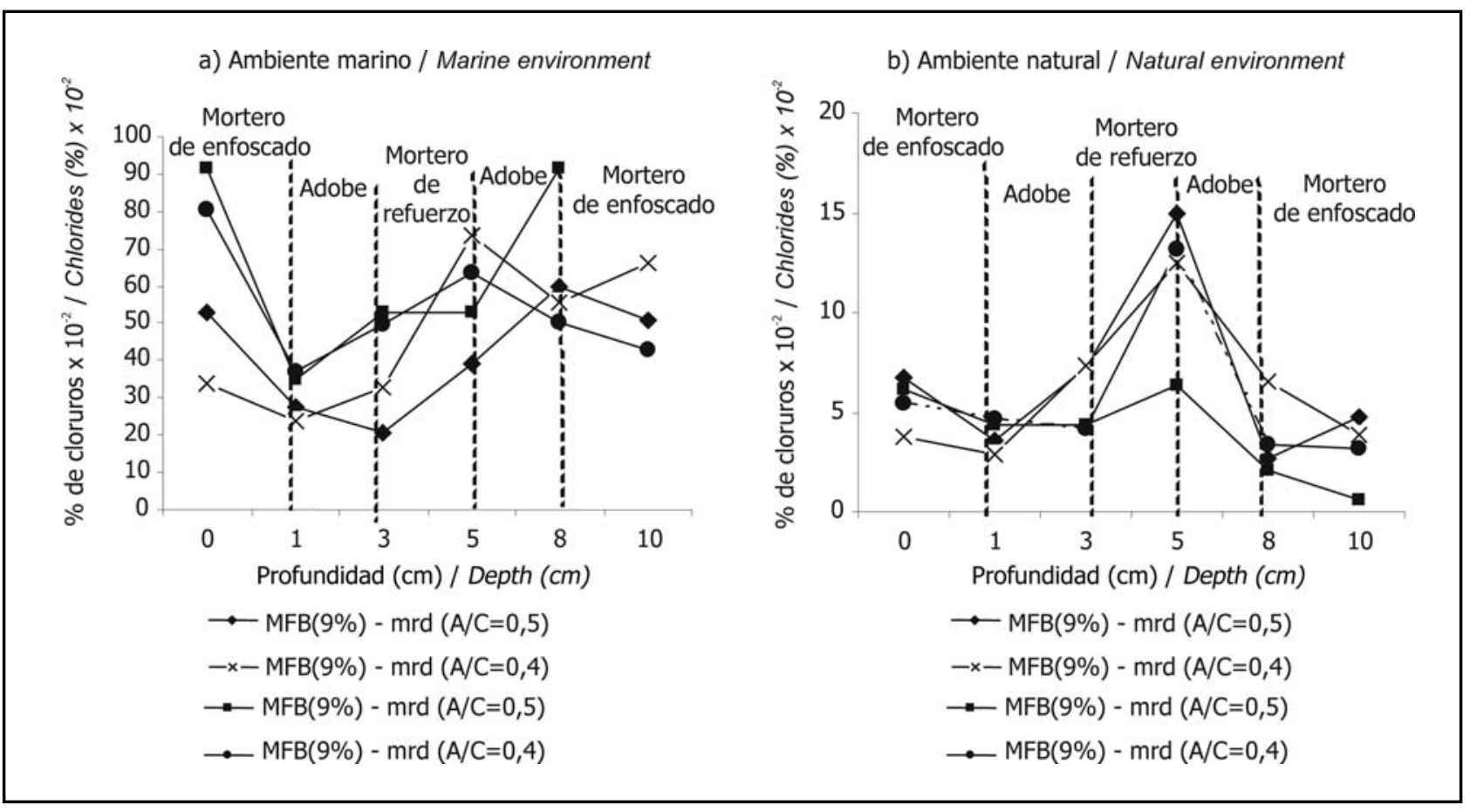

Figura 3. Porcentaje de cloruros por profundidad de extracción a los 1.000 días de exposición. Figure 3. Chloride content (per cent) vs depth after 1,000 days of exposure. 


\subsection{Inspección visual}

Con el propósito de verificar los resultados electroquímicos y químicos, se realizó una inspección del estado de los bloques, durante el periodo de exposición. Al final del periodo, se evaluó además el estado interno de las barras de acero.

\section{a) En los bloques}

Los bloques MFB ( $9 \%)$ - MRD $(a / c=0,5)$ y MFB $(9 \%)$ - $\operatorname{MRE}(a / c=0,4)$ expuestos tanto en ambiente natural como en ambiente marino simulado se deterioraron mucho durante el periodo de evaluación, siendo los más afectados los del ambiente marino, en donde, de manera generalizada, el mortero de enfoscado se desprendió y se observaron grietas longitudinales de aproximadamente $1 \mathrm{~mm}$ de espesor. Con respecto a las probetas MFA $(12 \%)$ - MRD $(a / c=0,5)$ y MFA $(12 \%)$ - MRE $(a / c=0,4)$ expuestas al ambiente natural, presentaron daños superficiales leves en el mortero de enfoscado, salvo algunas grietas longitudinales laterales en el sentido de las barras de aproximadamente $0,5 \mathrm{~mm}$ de espesor. Las probetas similares que estuvieron sometidas al ambiente marino simulado sí presentaron cierto grado de disgregación, grietas longitudinales laterales, e incluso pérdida del mortero de enfoscado en la zona frontal de la misma. Ver secuencia de fotos en la Figura 4.

\subsection{Visual inspection}

Specimens were visually inspected during the exposure period to verify the electrochemical and chemical results. At the end of the period, the steel bars were also inspected for state of repair.

\section{a) In the blocks}

Blocks MFB (9\%) - MRD $(w / c=0.5)$ and MFB (9\%) - $M R E(w / c=0.4)$, exposed to both natural and simulated marine environments, underwent substantial deterioration during the assay, although the marine medium specimens were more severely affected. Much of the rough casting had fallen away and longitudinal cracks approximately $1 \mathrm{~cm}$ thick were observed. The surface damage on the rough casting in the MFA (12\%) - MRD $(w / c=0.5)$ and MFA $(12 \%)-M R E(w / c=0.4)$ specimens that were exposed to a natural environment, in turn, was observed to be slight, with the exception of a few longitudinal cracks along the sides in the direction of the rebar, approximately $0.5 \mathrm{~mm}$ thick. Similar specimens exposed to a simulated marine environment did show some degree of disintegration, however, with longitudinal cracks along the sides and detachment of the rough casting across the front of the block. See the photographs in Figure 4.
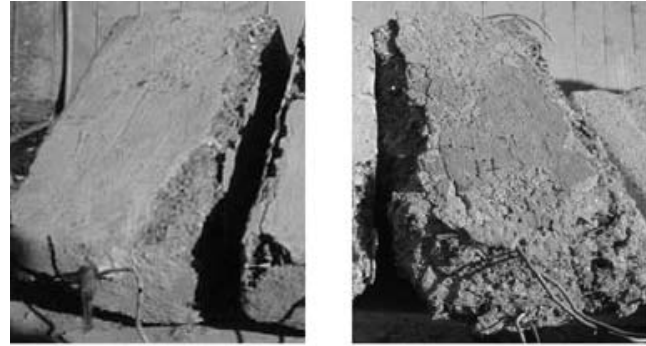

a) $\operatorname{MFB}(9 \%)-\operatorname{MRD}(\mathrm{a} / \mathrm{c}=0,5)$ : natural y marino a) $\operatorname{MFB}(9 \%)-M R D(w / c=0.5)$ : natural and marine
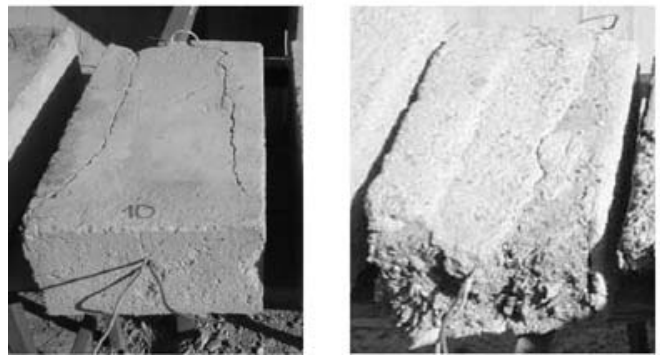

c) MFA $(12 \%)-\operatorname{MRD}(a / c=0,5)$ : natural y marino c) MFA (12\%) - MRD $(a / w=0.5)$ : natural and marine
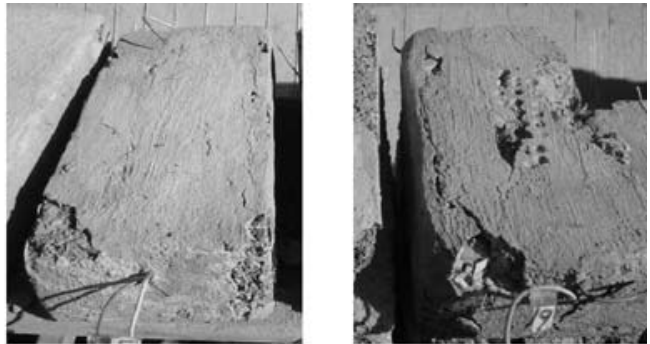

b) $\operatorname{MFB}(9 \%)-\operatorname{MRE}(a / c=0,4)$ : natural y marino b) $\operatorname{MFB}(9 \%)-\operatorname{MRE}(w / c=0.4)$ : natural and marine
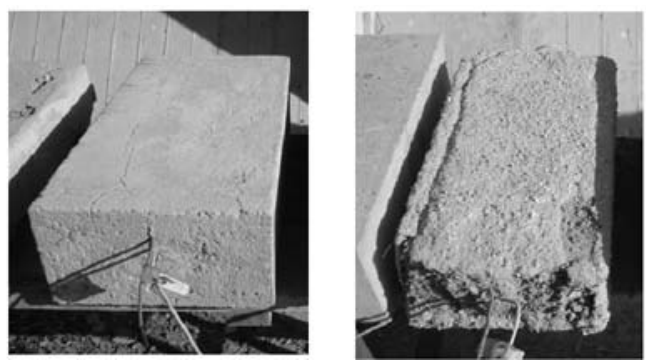

d) MFA $(12 \%)-\operatorname{MRE}(\mathrm{a} / \mathrm{c}=0,4)$ : natural y marino d) $\operatorname{MFA}(12 \%)-\operatorname{MRE}(w / c=0.4)$ : natural and marine

Figura 4. Comparación entre probetas en ambiente natural y en ambiente marino simulado a los 1.000 días de exposición. Figure 4. Comparison between natural and simulated marine environment specimens after 1,000 days of exposure. 
b) En las barras de acero

Para verificar el grado de deterioro del acero embebido en el mortero de refuerzo, se extrajeron las barras y se realizó igualmente una inspección visual. Se midieron las zonas afectadas por corrosión y se estimó el porcentaje de deterioro con respecto al área útil total.

Las barras de refuerzo embebidas en las probetas MFB $(9 \%)-\operatorname{MRD}(a / c=0,5)$ y $\operatorname{MFB}(9 \%)-\operatorname{MRE}(a / c=0,4)$ expuestas en ambiente natural no reportaron daños considerables por corrosión, sin embargo, presentaron manchas de corrosión en algunas zonas. Caso contrario ocurrió con las barras de acero de las probetas similares MFB $(9 \%)$ - MRE $(a / c=0,4)$ y MFB (9\%) - MRD $(a / c=0,5)$ expuestas al ambiente marino simulado, las cuales presentaron productos de corrosión en toda su longitud, pudiéndose observar picaduras de $2 \mathrm{~mm}$ de profundidad producto de la corrosión y zonas de desgaste pronunciado con pérdida de las estrías.

Las barras de acero extraídas de las probetas MFA $(12 \%)$ - MRD $(a / c=0,5)$ expuestas al ambiente natural fueron las que mejor condición reportaron, presentando algunas manchas de corrosión muy dispersas. En el caso de las barras extraídas de las probetas similares MFA $(12 \%)$ - MRD $(a / c=0,5)$ expuestas en ambiente marino simulado presentaron gran deterioro al encontrarse picaduras generalizadas a lo largo de unos $2 \mathrm{~mm}$ de profundidad y zonas de gran desgaste con pérdida de las estrías. Su estado es similar al encontrado en las probetas MFB $(9 \%)$ - MRE $(a / c=0,4)$ expuestas al mismo ambiente.

En cuanto a las barras de acero embebidas en el mortero de refuerzo de las probetas MFA $(12 \%)-\operatorname{MRE}(a / c=0,4)$ expuestas en ambiente natural no presentaron daños considerables de corrosión en su superficie, salvo algunas manchas de óxido en algunas zonas de las mismas. Las barras de probetas similares pero expuestas en ambiente marino simulado presentaron productos de corrosión, manchas de óxido e indicios de desgaste con pérdida parcial de estrías en muchas zonas de las barras de acero. De las probetas típicas que fueron estudiadas y fueron expuestas en ambiente marino simulado, ésta es la barra de acero que menor grado de corrosión presentó.

En la Tabla 1 se presenta en porcentaje el deterioro superficial de las barras de acero extraídas y su respectivo ambiente de exposición.

Si se establecen los límites de daños a los 1.000 días, en función del grado de deterioro del acero de armado, tenemos que las barras de todas aquellas probetas expuestas en ambiente natural se encuentra en muy buen estado con grado de deterioro entre 2,36\% y b) Steel bars

The rebar was removed and visually inspected to ascertain the degree of deterioration in the steel embedded in the reinforcement mortar. The corroded areas were measured and the percentage of deterioration with respect to the total area was estimated.

No substantial corrosion damage was found in the rebar embedded in specimens MFB (9\%) - MRD (w/c=0.5) or $\operatorname{MFB}(9 \%)$ - MRE $(w / c=0.4)$ exposed to a natural environment, although some scattered corroded spots were observed. On the contrary, the steel bars in similar specimens - MFB (9\%) - MRE $(w / c=0.4)$ and MFB (9\%) - $M R D(w / c=0.5)$ - exposed to a simulated marine environment exhibited corrosion products along their entire length, including punctures $2 \mathrm{~mm}$ deep and areas of severe wear in which the ribs had vanished altogether.

The steel bars found to be in the best condition, with only a few scattered corrosion spots, were the ones removed from the MFA (12\%) - MRD $(w / c=0.5)$ specimens that had been exposed to a natural environment. The bars removed from similar specimens - MFA (12\%) - $\operatorname{MRD}(a / c=0.5)$ - exposed to a simulated marine environment were severely deteriorated, with punctures 2 $\mathrm{mm}$ deep along the entire length as well as very worn areas where the ribs had eroded away completely. These findings were very similar to the observations for the MFB (9\%) - MRE (w/c=0.4) specimens, likewise exposed to a marine environment.

No substantial corrosion damage was found on the surface of the rebar embedded in specimens MFA (12\%) - MRE $(w / c=0.4)$ exposed to a natural environment, with the exception of a few scattered rust spots. Corrosion products were observed on the rebar in similar specimens exposed to a simulated marine environment, including rust spots and signs of wear with partial erosion of the ribs in many areas of the steel. Of all the specimens studied and exposed to a simulated marine environment, this was the one with the least corrosion in the steel bars.

The percentage of surface deterioration in the steel bars removed from specimens exposed to the two environments is given in Table 1 .

Defining the 1,000-day damage threshold in terms of the degree of reinforcing steel deterioration, the rebar in all the specimens exposed to a natural environment could be regarded to be in good condition, with deterioration rates ranging from 2.36 to $13.64 \%$, despite the relatively 
Tabla 1 / Table 1

Grado de deterioro presente en el acero de refuerzo

Deterioration in reinforcing steel

\begin{tabular}{|c|c|c|}
\hline $\begin{array}{c}\text { Tipo } \\
\text { Type }\end{array}$ & $\begin{array}{c}\text { Ambiente natural } \\
\text { Natural environment }\end{array}$ & $\begin{array}{c}\text { Ambiente marino simulado } \\
\text { Simulated marine environment }\end{array}$ \\
\hline MFB $(9 \%)-\operatorname{MRD}(\mathrm{a} / \mathrm{c}=0.5)$ & $13.64 \%$ & $78.18 \%$ \\
\hline MFA $(12 \%)-\operatorname{MRD}(\mathrm{a} / \mathrm{c}=0.5)$ & $2.36 \%$ & $90.91 \%$ \\
\hline MFB $(9 \%)-\operatorname{MRE}(\mathrm{a} / \mathrm{c}=0.4)$ & $12.27 \%$ & $100 \%$ \\
\hline MFA $(12 \%)-\operatorname{MRE}(\mathrm{a} / \mathrm{c}=0.4)$ & $5.91 \%$ & $62.27 \%$ \\
\hline
\end{tabular}

$13,64 \%$, a pesar de que los porcentajes de cloruros en todos los casos está entre $0,05 \%$ - 0,15\%. De las expuestas en ambiente marino simulado, la probeta tipo MFA $(12 \%)$ - MRE $(a / c=0,4)$ se encuentra en mejor estado que la probeta tipo MFA (12\%) - MRD $(a / c=0,5)$, con lo que podemos decir que en ambientes agresivos la menor relación agua-cemento en el mortero de refuerzo disminuye la penetración de cloruros. Las probetas tipo MFB $(9 \%)$ - MRD $(a / c=0,5)$ y tipo MFB $(9 \%)$ - MRE $(a / c=0,4)$ expuestas igualmente en ambiente marino simulado se encuentran en muy mal estado, con grados de deterioro entre $78,18 \%$ y $100 \%$.

\section{CONCLUSIONES}

Todas las probetas en ambiente marino simulado, de acuerdo con las propiedades de potencial de corrosión, velocidad de corrosión y cloruros libres cuantificados, presentan valores que indican actividad de corrosión de moderada a alta en la armadura, comprobándose con la inspección visual la presencia de corrosión por picaduras, por lo tanto no se recomienda este tipo de material en ambientes marinos. Para las probetas expuestas en ambiente natural, los valores reportados de estas propiedades evidencian una actividad de corrosión moderada en el acero de refuerzo, aun cuando las probetas de MFB ( $9 \%$ ) presentaron un gran deterioro en el bloque de adobe, no se observó corrosión en las barras. En general, las probetas más afectadas fueron las de más bajo contenido de cemento en el mortero de enfoscado MFB ( $9 \%$ ), lo cual ratifica que en los diseños con adobes se debe cuidar más el mortero de enfoscado, que el mortero de refuerzo, ya que el deterioro afecta a todo el elemento.

\section{AGRADECIMIENTOS}

Los autores agradecen al Consejo de Desarrollo Científico, Humanístico y Tecnológico (CDCHT) de la Universidad Centroccidental "Lisandro Alvarado", por el financiamiento otorgado para la prosecución de este proyecto. También expresan su agradecimiento a los técnicos del laboratorio de Química de los Materiales y de Materiales high chloride content values: from 0.05 to $0.15 \%$. Of the specimens exposed to a simulated marine environment, specimen MFA (12\%) - MRE $(w / c=0.4)$ was found to be in better condition than specimen MFA (12\%) - MRD $(w / c=0.5)$, inferring that in aggressive environments reinforcement mortars with a lower water-cement ratio reduce chloride penetration. Specimens MFB (9\%) - MRD $(a / c=0.5)$ and MFB (9\%) - MRE $(a / c=0.4)$, likewise exposed to a simulated marine environment, were found to be in very poor condition, with deterioration rates of from $78.18 \%$ to $100 \%$.

\section{CONCLUSIONS}

Pursuant to electrochemical potential, corrosion rate and chloride content results, all the specimens exposed to a simulated marine environment exhibited values indicative of moderate to high rebar corrosion, while a visual inspection revealed the presence of punctures. Consequently, this type of material cannot be recommended for use in marine environments. The values observed for the above parameters in specimens exposed to natural environments were indicative of moderate corrosion in the reinforcing steel; although the adobe in the MFB (9\%) specimens was severely deteriorated, the bars were not corroded. Generally speaking, the specimens most severely damaged were the ones with a lower cement content in the rough casting mortar, i.e., specimens MFB (9\%). This ratifies the premise that in adobe design, greater attention should be lent to the rough casting than the reinforcement mortar, since deterioration in the former affects the entire member.

\section{ACKNOWLEDGEMENTS}

The present project was funded by the Lisandro Alvarado Western Central University's Council for Scientific, Humanistic and Technological Development (CDCHT). The authors wish to thank the Materials Chemistry and Construction Materials Laboratory (Department of Civil Engineering) technicians for their assistance and the 
de Construcción del Decanato de Ingeniería Civil y al Instituto Eduardo Torroja por haber reconocido a este trabajo, como mejor trabajo inédito en el Congreso de Patología y Control de Calidad, CONPAT 2005, realizado en Asunción-Paraguay.
Eduardo Torroja Institute for acknowledging this report as the best unpublished paper submitted to the Pathology and Quality Control Congress, CONPAT 2005, held at Asunción, Paraguay.

\section{BIBLIOGRAFÍA / BIBLIOGRAPHY}

(1) Pérez, G.; Melo, R.; Rojas, H.; Castro, L.; Malavé, R.; Anzola, E. y López, G.: "Evaluación de las propiedades físicas del adobe reforzado y de sus materiales componentes y su influencia en el comportamiento electroquímico", Mater. Construcc., vol. 54, n² 274 (2004), pp. 5-16.

(2) Red DURAR-CYTED: "Manual de Inspección, Evaluación y Diagnostico de Corrosión en estructuras de Hormigón Armado", CYTED, España, 2a edición 1998, p. 121.

(3) Andrade, C.: "Vida útil de las estructuras de hormigón armado: obras nuevas y deterioradas". Curso de Estudios Mayores de la Construcción (CEMCO, 1995). Seminario Reparación de Estructuras de Hormigón Dañadas por Corrosión (1995).

(4) Pérez, G.; Melo, R. y Malavé, R. E.: "Caracterización de la permeabilidad, porosidad y absorción capilar de los muros portantes de adobe reforzado y sus materiales componentes", Memorias del Colloquia 2002, LUZ-UCLA Maracaibo-Venezuela, 2002. 